\title{
Development of monoclonal antibodies to iron-regulated outer membrane proteins and lipopolysaccharide of Aeromonas salmonicida
}

\author{
Beena Neelam $^{1}$, Kim D. Thompson ${ }^{2, *}$, Nicholas C. Price ${ }^{1}$, Mary F. Tatner ${ }^{3}$, \\ Alexandra Adams ${ }^{2}$, Anthony E. Ellis ${ }^{4}$, Lewis Stevens ${ }^{1}$ \\ ${ }^{1}$ Department of Biological and Molecular Sciences, University of Stirling, Stirling FK9 4LA, Scotland, UK \\ ${ }^{2}$ Institute of Aquaculture, University of Stirlíng, Stirling FK9 4LA, Scotland, UK \\ ${ }^{3}$ Department of Zoology, University of Glasgow, Glasgow G12 8QQ, Scotland, UK \\ ${ }^{4}$ SOAFD Marine Laboratory, PO Box 101, Victoria Rd, Aberdeen AB9 8DB, Scotland, UK
}

\begin{abstract}
Two monoclonal antibodies (MAbs) were obtained against the iron-regulated outer membrane proteins (IROMPs) and 4 MAbs were obtained against the lipopolysaccharide (LPS) of Aeromonas salmonicida, as demonstrated by immunoblotting. MAbs directed against LPS reacted with whole bacteria, both in the enzyme linked immunosorbent assay (ELISA) and by the indirect fluorescent antibody technique (IFAT). Of the 2 MAbs directed against the IROMPs, one did not react with whole bacteria either by IFAT or by ELISA, whereas the other reacted weakly with whole bacteria in both the tests. Some potential applications of the MAbs, including screening of bacterial isolates, are also discussed
\end{abstract}

KEY WORDS: Aeromonas salmonicida - Iron-regulated outer membrane proteins - Lipopolysaccharide Monoclonal antibodies

\section{INTRODUCTION}

Aeromonas salmonicida is the causative agent of furunculosis in salmonids (Trust 1986). This bacterium has been shown to effectively scavenge iron from ironbinding proteins of the host such as transferrin and lactoferrin, as well as from the low-molecular-weight chelating agent ethylenediamine dihydroxyphenylacetic acid (EDDA) (Chart \& Trust 1983). Chart \& Trust (1983) and Neelam et al. (1993) have found that bacteria grown in the presence of various iron-chelating agents showed a marked increase in the proportion of proteins in the outer membrane above the 70 kilodalton $(\mathrm{kDa})$ range. Four iron-regulated outer membrane proteins (IROMPs) with molecular weights of $70,72,77$, and $82 \mathrm{kDa}$ have been found to confer significant protection against $A$. salmonicida in Atlantic

- Addressee for correspondence salmon Salmo salar L. when the fish, immunised with these proteins, experienced a natural or experimental challenge with the bacterium (Hirst \& Ellis 1994). To develop a method for identification and quantitative determination of IROMPs and lipopolysaccharide (LPS) in A. salmonicida, we produced monoclonal antibodies (MAbs) against these antigens.

\section{MATERIALS AND METHODS}

Growth of Aeromonas salmonicida. A. salmonicida strain MT 004 (a Scottish isolate from Salmo salar) was obtained from SOAFD Marine Laboratory, Aberdeen, Scotland. It was maintained on Petri dishes containing $4 \%(\mathrm{w} / \mathrm{v})$ tryptic soy agar (Gibco, Paisley, Scotland). A. salmonicida was grown for $24 \mathrm{~h}$ at $25^{\circ} \mathrm{C}$ in an orbital incubator $(100 \mathrm{rpm})$ in $50 \mathrm{ml}$ batches in a medium containing 3\% (w/v) tryptic soy broth (TSB) (Price et al. 1989) and to which 2,2 -dipyridyl (dipy) $(0.1 \mathrm{mM})$ had 
been added. At the end of the growth period (when the optical density at $610 \mathrm{~nm}$ had reached a value of approximately 6 , corresponding to $3 \times 10^{9}$ cells $\mathrm{ml}^{-1}$ ), the suspension was centrifuged at $13000 \times \mathrm{g}$ for $10 \mathrm{~min}$ to obtain the bacterial pellet.

Extraction of outer membrane proteins (OMPs). The bacterial pellet obtained from $50 \mathrm{ml}$ of culture was washed twice by resuspending in $8 \mathrm{ml}$ of envelope buffer (10 mM Tris- $\left.\mathrm{HCl}_{1} \mathrm{pH} 7.0\right)$ and centrifuging at $13000 \times g$ for $10 \mathrm{~min}$. After the final wash, the pellet was resuspended in $8 \mathrm{ml}$ of envelope buffer. The cells were disrupted by sonication on ice $(6 \times 30 \mathrm{~s}$, amplitude $9 \mu \mathrm{m}$ ) and inner and outer membranes were separated by differential extraction using $0.75 \%(\mathrm{w} / \mathrm{v})$ sodium laurylsarcosinate (Filip et al. 1973).

Extraction of LPS. Strain MT 004 was grown in TSB for $48 \mathrm{~h}$ at $22^{\circ} \mathrm{C}$ with shaking. Bacterial cells were washed in phosphate buffered saline (PBS) $(20 \mathrm{mM}$ sodium phosphate, $150 \mathrm{mM} \mathrm{NaCl}, \mathrm{pH} \mathrm{7.2)}$ and the LPS extracted by hot phenol (Westphal \& Jann 1965) and lyophilised

SDS-PAGE. Sodium dodecyl sulfate polyacrylamide gel electrophoresis (SDS-PAGE) was performed by the method of Laemmli (1970) using 10\% acrylamide separating gels. Following electrophoresis, the gels were stained either in $0.1 \%(\mathrm{w} / \mathrm{v})$ Coomassie Blue R250 or by using a silver stain kit (BIO-RAD).

Purification of IROMPs. IROMPs were purified from the OMP preparation by subjecting the crude OMPs to SDS-PAGE on a $10 \%$ polyacrylamide slab gel of $1.5 \mathrm{~mm}$ thickness, cast with a preparative comb. Outer membrane protein (500 $\mu$, containing approximately $100 \mu \mathrm{g}$ protein, in 2\% SDS), diluted $1: 1$ in sample buffer [0.5 M Tris- $\mathrm{HCl}, 10 \%$ (v/v) glycerol, $0.05 \%$ (w/v) bromophenol blue, $10 \%$ (w/v) SDS, 2-mercaptoethanol], was heated to $100^{\circ} \mathrm{C}$ for $5 \mathrm{~min}$ in a water bath before loading onto the preparative gel. After electrophoresis, the IROMPs-containing band was located on the gel by staining the gel for less than 2 min in $0.1 \%$ Coomassie Blue R250 in distilled water and the band above $90 \mathrm{kDa}$ (see Fig. 1a, Lane 3) was excised using a scalpel. The contents of the excised gel slice were electroeluted using a Biotrap BT 1000 apparatus (Schleicher and Schuell, Dassel, Germany) at $100 \mathrm{~V}$ overnight in elution buffer $[25 \mathrm{mM}$ Tris-HCl, $192 \mathrm{mM}$ glycine, 0.025\% (w/v) SDS] and subsequently electrodialysed at $200 \mathrm{~V}$, according to the manufacturer's instructions. A modified Lowry procedure (Markwell et al. 1981) was used to estimate the protein concentration in these fractions. When the electroeluted material was re-run on SDSPAGE, the apparent molecular weight was in the $80 \mathrm{kDa}$ region (see Fig. 1a, Lane 2). The reason for the lower mobility of this band in the crude outer membrane preparation is not clear, but it could reflect interactions between the components of this preparation.
Immunisation schedule. The fragmented wet gel slice was used for primary injection. The antigen (IROMPscontaining gel slice, prepared as described by Harlow \& Lane 1988) was injected, without adjuvant, intraperitoneally into four $8 \mathrm{wk}$ old Balb/c mice $[200 \mu \mathrm{l} \mathrm{elec-}$ troeluted sample ( $80 \mu \mathrm{g}$ protein) mouse $\left.{ }^{-1}\right]$. Electroeluted material from the band above $90 \mathrm{kDa}$ was used for subsequent booster injections [200 $\mathrm{\mu l}$ of electroeluted sample mixed with $200 \mu \mathrm{ll} 0.85 \%$ (w/v) saline mouse ${ }^{-1}$ ] at $4 \mathrm{wk}$ and $9 \mathrm{wk}$ after the first injection. Antibody production was monitored using an ELISA procedure (see below) by 'sensitising' the microtitre plate with $1 \mu \mathrm{g}$ protein $\mathrm{ml}^{-1}$ of electroeluted samples. Four days prior to the preparation of hybridomas, the mouse was given a final booster injection, intravenously, with electroeluted sample $[200 \mu \mathrm{l}+200 \mu \mathrm{l} 0.85 \%$ (w/v) saline $]$.

Hybridoma production. Monoclonal antibodies were produced by 3 separate fusions using the method of Adams et al. (1992). Two weeks after fusion, the supernatants were screened by an ELISA procedure. Selected hybridomas producing antibodies reactive with antigens in the electroeluted material were cloned in 96 -well tissue culture plates by preparing cell suspensions of $25,12.5,6.25$, and 3.12 cells ml $^{-1}$ in the selective culture medium with mouse red blood cells as feeders. The supernatants were screened by ELISA 2 wk after cloning and selected single positive clones were cloned again. After screening again by the ELISA procedure, selected single clones were expanded into 24-well tissue culture plates (Costar) and subsequently into tissue culture flasks (Gibco, Paisley, Scotland) and maintained in Dulbecco's Modified Eagle Medium (DMEM) containing glutamine, penicillin, streptomycin, and $10 \%$ foetal calf serum.

Screening hybridomas. ELISA procedure: Antibodies specific to the sample electroeluted from the gel slice (see Fig. 1a, Lane 3), representing the band above $90 \mathrm{kDa}$, were detected using an ELISA procedure which was a modification of the method described by Hirst (1993). Samples which were electroeluted from the gel slice as described above were used as the antigen. Microtitre plates (Greiner Labortechnik, Dursley, England) were 'sensitised' with the antigen by coating the plates with serial dilutions of the antigen (5 to $0.1 \mu \mathrm{g}$ protein well $\left.{ }^{-1}\right)$ in bicarbonate buffer $(0.05 \mathrm{M}$, $\mathrm{pH}$ 9.6) and incubating overnight at $22^{\circ} \mathrm{C}$. Plates were washed twice with $250 \mu \mathrm{lTBS}$ [20 mM Tris- $\mathrm{HCl}$, $500 \mathrm{mM} \mathrm{NaCl}$, pH 7.5 containing $0.05 \%$ (v/v) Tween20] well $^{-1}$ and then blocked by incubating them with $100 \mu \mathrm{l}$ of $5 \%(\mathrm{v} / \mathrm{v})$ normal goat serum in TTBS well ${ }^{-1}$ for $2 \mathrm{~h}$ at $22^{\circ} \mathrm{C}$. After 2 washes, samples, either antisera from test bleeds or undiluted supernatant from hybridomas, were added to the wells $\left(100 \mu \mathrm{l}\right.$ well $\left.{ }^{-1}\right)$ and incubated at $22^{\circ} \mathrm{C}$ for $1 \mathrm{~h}$. Negative controls (normal mouse serum) and positive controls (mouse serum 
positive to the antigens) were included in the test. Excess unbound antibodies were removed by washing the plates twice as described above. Goat anti-mouse Immunoglobulin G-Horseradish Peroxidase (IgGHRP) conjugate at $1: 1000$ dilution was added to all the wells $\left(100 \mu \mathrm{l} \mathrm{well} \mathrm{l}^{-1}\right)$ and incubated at $22^{\circ} \mathrm{C}$ for $1 \mathrm{~h}$. Plates were washed once in TTBS and twice in TBS (20 mM Tris- $\mathrm{HCl}, 500 \mathrm{mM} \mathrm{NaCl}, \mathrm{pH} 7.5$ ) to remove unbound conjugate before the assay was developed by adding $100 \mu \mathrm{l}$ chromogen ( $43 \mathrm{mM}$ tetramethyl benzidine dihydrochloride in $2 \mathrm{M}$ acetic acid) diluted $1: 100$ in substrate buffer $(0.1 \mathrm{M}$ citric acid, $0.1 \mathrm{M}$ sodium acetate, $\mathrm{pH} 5.4$ ) containing $0.33 \%(\mathrm{v} / \mathrm{v}) \mathrm{H}_{2} \mathrm{O}_{2}$ well ${ }^{-1}$. The reaction was terminated after 15 to $30 \mathrm{~min}$ by adding $50 \mu$ l of $2 \mathrm{M} \mathrm{H}_{2} \mathrm{SO}_{4}$ well ${ }^{-1}$. The absorbance at $450 \mathrm{~nm}$ was measured using an ELISA reader (Dynatec MR 5000). Positive wells were yellow in colour while negative wells remained clear. The optimum concentration of antigen was found to be $0.1 \mu \mathrm{g}$ protein well ${ }^{-1}$ which was used in the ELISA tests for screening the hybridomas. The goat anti-mouse IgG-HRP conjugate and goat normal serum were obtained from the Scottish Antibody Production Unit, Carluke, Lanarkshire, Scotland.

Western blotting: Hybridomas were screened using the western blotting technique described by Towbin et al. (1979), with modifications. Either electroeluted IROMPs sample $\left(50 \mu \mathrm{l}\right.$ of $200 \mu \mathrm{g}$ protein $\mathrm{m}^{-1}$ solution in elution buffer $+50 \mu$ sample buffer) or the hotphenol-extracted Aeromonas salmonicida LPS (50 $\mathrm{\mu l}$ of a $2 \mathrm{mg}$ dry $w \mathrm{t} \mathrm{ml}^{-1}$ solution in distilled water $+50 \mu \mathrm{l}$ sample buffer) was subjected to electrophoresis on a SDS-polyacrylamide mini-gel (BIO-RAD) and then transferred from the gel to a sheet of nitrocellulose membrane by a semi-dry blotting method (KhyseAndersen 1984) using a Trans-Blot SD Semi-Dry Electrophoretic Transfer Cell (BIO-RAD), according to the manufacturer's instruction manual, at $15 \mathrm{~V}$ for 20 min. Following transfer, the nitrocellulose membrane was washed in 2 changes of TTBS, and then blocked for $2 \mathrm{~h}$ in $0.5 \%(\mathrm{w} / \mathrm{v})$ casein in distilled water The membrane was then washed twice in TTBS and antisera from test bleeds which were positive to the electroeluted sample or undiluted supernatants from hybridomas were applied to the nitrocellulose membrane in the multiscreen apparatus (BIO-RAD) and incubated overnight at $4^{\circ} \mathrm{C}$. After 2 washes in TTBS, goat anti-mouse IgG-HRP conjugate at a dilution of $1: 100$ in $0.5 \%$ casein was applied to all the lanes of the membrane and incubated at room temperature for $1 \mathrm{~h}$. Unbound conjugate was removed from the membrane by washing once in TTBS followed by two washes in TBS. The assay was developed by adding DAB peroxidase substrate (each SIGMA FAST ${ }^{\mathrm{TM}}$ 3, 3'-diaminobenzidine tablet set dissolved in $15 \mathrm{ml}$ distilled water).
Cross reactivity by ELISA. The specificities of the monoclonal antibodies to Aeromonas salmonicida IROMPs and LPS antigens were examined using a direct ELISA against a range of bacterial cultures (Table 1). Twenty-nine isolates of A. salmonicida, obtained from Atlantic salmon during furunculosis outbreaks on the west coast of Scotland, were also included in the screening. Isolates were supplied by Dr V. Inglis, Institute of Aquaculture Diagnostic Unit, University of Stirling. Bacterial samples were cultured in TSB and prepared for the ELISA by washing twice with PBS and adjusting the cell concentration to $3 \times$ $10^{8} \mathrm{ml}^{-1}$ in PBS by measurement of the optical density at $610 \mathrm{~nm}$ (Adams \& Thompson 1990). In addition, strain MT 423 (SOAFD Marine Laboratory, Aberdeen) was cultured under a variety of iron-restricted and iron-supplemented conditions.

Microtitre wells were coated with $100 \mu \mathrm{l}$ of $0.05 \mu \mathrm{g}$ poly-L-lysine $\mathrm{ml}^{-1}$ in bicarbonate buffer and incubated at $20^{\circ} \mathrm{C}$ for $60 \mathrm{~min}$. Plates were washed twice with $20 \mathrm{mM}$ Tris- $\mathrm{HCl}, 380 \mathrm{mM} \mathrm{NaCl}, 0.05 \%$ (v/v) Tween20, $\mathrm{pH} 7.8$. Bacteria $\left(100 \mu \mathrm{l}\right.$ well $\left.{ }^{-1}\right)$ were dispensed into the plates and centrifuged for $5 \mathrm{~min}$ at $900 \times \mathrm{g}$. Aeromonas salmonicida strain MT 004 was used as a positive control and PBS was used as a negative control. Plates were incubated for 60 min at $20^{\circ} \mathrm{C}$ before adding $50 \mu \mathrm{l}$ of $0.05 \%$ (v/v) glutaraldehyde in PBS well ${ }^{-1}$ and incubated for a further $20 \mathrm{~min}$. Unbound bacteria were removed by washing as described above and the plates were blocked with $5 \%(\mathrm{w} / \mathrm{v})$ dried milk. (Marvel, Premier Brands UK Ltd) in distilled water

Table 1. Bacterial cultures used to test the specificity of the monoclonal antibodies to Aeromonas salmonicida

\begin{tabular}{|c|c|}
\hline \multicolumn{2}{|c|}{ Source ${ }^{d}$ and number } \\
\hline Aeromonas hydrophila & NCMB 1134 \\
\hline Aeromonas punctata & NCMB 74 \\
\hline Aeromonas salmonicida achromogenes & NCMB 1109 \\
\hline Edwardsiella tarda & IOA \\
\hline Escherichia coli & IOA \\
\hline Haemophilus piscuim & NCMB 1952 \\
\hline Nacardia asteroides & NCMB 1890 \\
\hline Pseudomonas anguiliseptica & NCMB 2185 \\
\hline Pseudomonas fluorescens & NCMB 1953 \\
\hline Pseudomonas aeruginosa & ATCC 27853 \\
\hline Renibacterium salmoninarum & IOA \\
\hline Serratia sp. & IOA \\
\hline Streptococcus faecalis & IOA \\
\hline Vibrio anguillarum & IOA \\
\hline Vibrio ordalij & NCMB 2167 \\
\hline Vibrio salmonicida & NCMB 2262 \\
\hline Yersinia ruckeri & NCMB 1316 \\
\hline \multicolumn{2}{|c|}{$\begin{array}{l}\text { aNCMB: National Collection of Marine Bacteria; IOA: } \\
\text { Institute of Aquaculture; ATCC: American Type Culture } \\
\text { Collection }\end{array}$} \\
\hline
\end{tabular}


$\left(250 \mu \mathrm{l}\right.$ well $^{-1}$ for $2 \mathrm{~h}$ at $\left.20^{\circ} \mathrm{C}\right)$. The remaining steps of the ELISA procedure were identical to those outlined for the hybridoma screening

Indirect fluorescent antibody technique (IFAT). IFAT was carried out according to Anderson (1990) using 1/100 dilutions of rabbit anti-Aeromonas salmonicida for the positive control and normal mouse serum for the negative control. A $1 / 100$ dilution of either fluorescein isothiocyanate (FITC)-donkey anti-rabbit IgG or FITC-donkey anti-mouse IgG (SAPU) was used as the secondary antibody.

\section{RESULTS}

\section{Isolation and examination of IROMPs-containing fraction from the outer membrane of Aeromonas salmonicida}

The crude OMP preparation (Fig. 1a, Lane 3) and the material electroeluted from the IROMPs region (i.e. the band $>90 \mathrm{kDa}$ ) after gel electrophoresis of the crude OMP (Fig. 1a, Lane 2) were analysed by SDS-PAGE. After electroelution, the mobility of the IROMPs components appeared to increase and the components were more sharply defined (compare Lanes 2 and 3). Using Coomassie Blue to detect protein, the electroeluted material consisted of 2 main bands and 2 other very minor bands (not distinct in Fig. 1a), all in the 70 to $90 \mathrm{kDa}$ range as previously noted (Chart \& Trust 1983, Neelam et al. 1993, Hirst \& Ellis 1994).

The OMP preparation and the electroeluted IROMPs fraction were also analysed by SDS-PAGE, using a silver stain procedure. A sample of LPS extracted from Aeromonas salmonicida cells was also analysed by this procedure (Fig. 1b). The electroeluted material showed a number of prominent bands in the 70 to $150 \mathrm{kDa}$ region as well as other bands, many of them weak, in the 45 to $70 \mathrm{kD}$ a range (Lane 2). On treatment of the IROMPs fraction with proteinase $\mathrm{K}(25 \% \mathrm{w} / \mathrm{w}$ on the basis of protein; $60^{\circ} \mathrm{C}, 60 \mathrm{~min}$ ) most of the bands in the 70 to $90 \mathrm{kDa}$ region were no longer visible (Lane 4), although the weak bands above and below this range were still present. LPS (hot phenol extracted) showed 2 distinct bands in the $50 \mathrm{kDa}$ region (Lane 3 ). These bands could not be detected when the gel was stained with Coomassie Blue (data not shown). The weak bands above $90 \mathrm{kDa}$ detected by silver staining after proteinase $\mathrm{K}$ treatment (Lane 4) may have represented traces of residual undigested proteins, or may have represented a form of LPS present in the cells prior to the hot phenol treatment. The results shown in Fig. 1 led to the conclusion that the IROMPs-containing fraction propared by electroelution contained non-protein components (LPS) as well as proteins. The presence of LPS in the IROMPs-containing fraction was also indicated by the reactivity of the MAbs (see below).

\section{Reactivity of the MAbs}

Six hybridomas producing antibodies to the electroeluted IROMPs fraction were identified after screening by the ELISA procedure outlined. All the antibodies were classified as IgG1 by an isotyping kit (Sigma Chemical Co., Poole, England). Further analysis of these antibodies by western blotting (Fig. 2) showed that 2 of the antibodies (2G3 and 3C6) reacted only with the IROMPs (Lanes 8 and 14) and 4 antibodies (3A1, 3A3, 6G2, and 9F7) reacted with LPS (Lanes 5, 7, 11, and 13). The antisera from the mouse bleed reacted
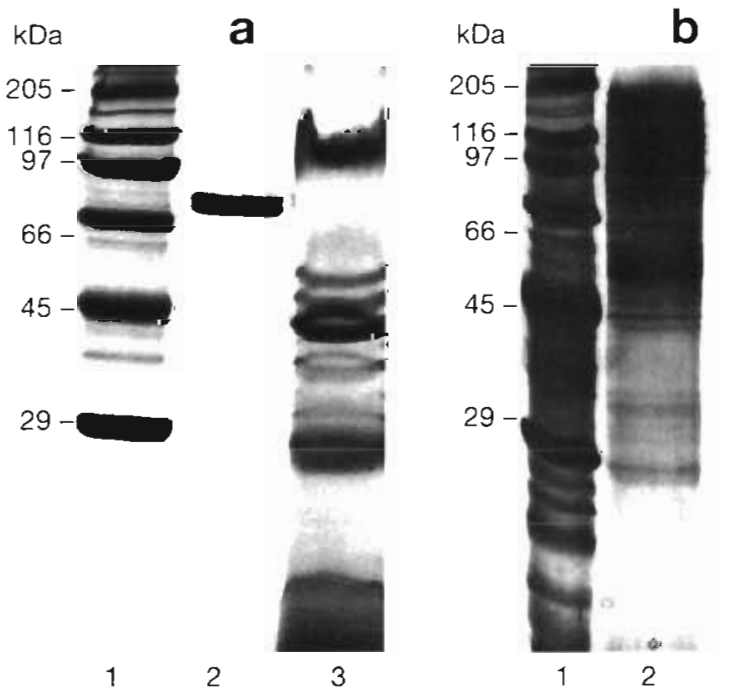

Fig. 1. Aeromonas salmonicida. (a) Separation of OMPs and IROMPs fractions by SDS-PAGE. The gel was stained with Coomassie Blue. Lane 1 represents high-molecular-weight markers, Lane 2 represents electroeluted IROMPs derived from the band above $90 \mathrm{kDa}$ seen in Lane 3 , and Lane 3 represents crude outer membrane proteins preparation. Approximately $15 \mu \mathrm{g}$ protein was applied to each lane. (b) Separation of OMPs, IROMPs, and LPS fractions by SDS-PAGE and their detection by silver staining. Lane 1 represents high-molecular-weight markers, Lane 2 represents electroeluted IROMPs, Lane 3 represents hot phenol extracted LPS, and Lane 4 represents IROMPs treated with proteinase $\mathrm{K}$ as described in the text. Approximately $1.0 \mu \mathrm{g}$ protein or LPS was applied to each lane 


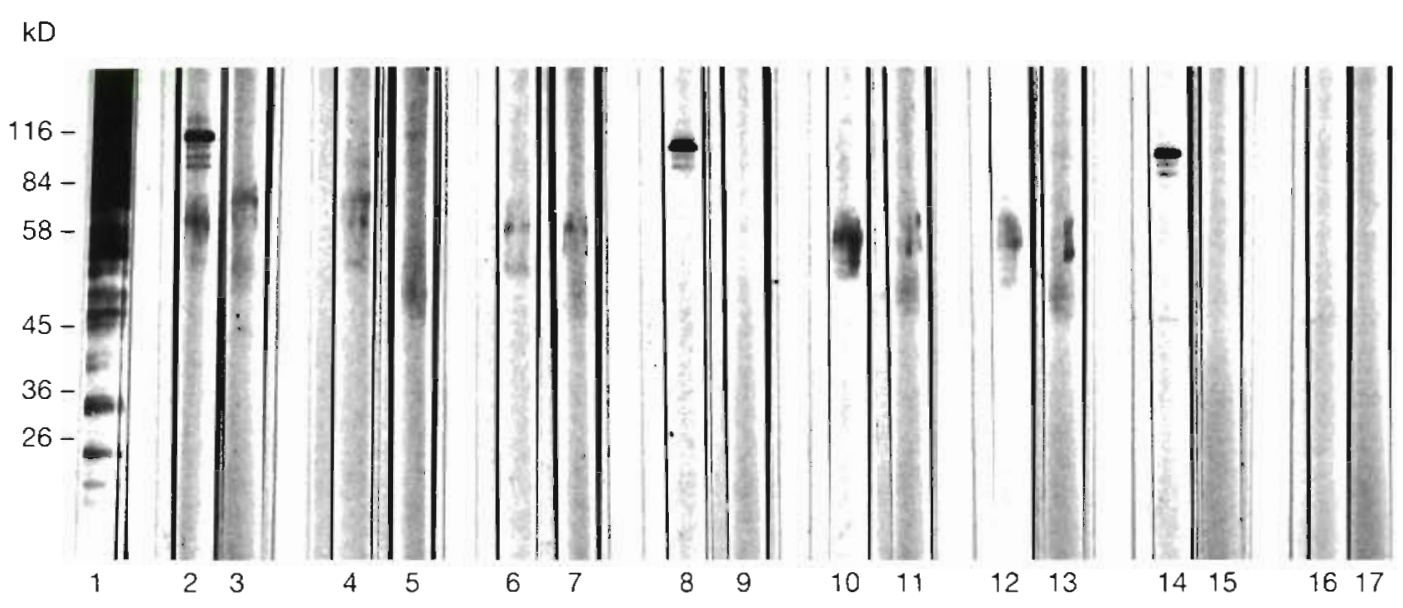

Fig. 2. The response of the MAb, positive mouse serum, and pre-immune mouse serum to the OMPs, IROMPs, and LPS fractions as shown by immunoblot analysis. 3A1, 3A3, 2G3,6G2, 9F7, and 3C6 are the MAbs described in the text. Lane: (1) positive mouse serum vs OMPs, (2) positive mouse serum vs IROMPs, (3) positive mouse serum vs LPS, (4) 3A1 vs IROMPs, (5) 3A1 vs LPS, (6) $3 A 3$ vs IROMPs, (7) $3 A 3$ vs LPS, (8) 2 G3 vs IROMPs, (9) 2 G3 vs LPS, (10) 6 G2 vs IROMPs, (11) 6 G2 vs LPS, (12) 9F7 vs IROMPs, (13) 9F7 vs LPS, (14) 3C6 vs IROMPs, (15) 3C6 vs LPS, (16) negative mouse serum vs IROMPs, (17) negative mouse serum vs LPS

with the total OMPs (Lane 1), with IROMPs (Lane 2) and with LPS (Lane 3).

The specificities of the MAbs to either the IROMPs or the LPS of Aeromonas salmonicida were confirmed by examining their reactivity with the electroeluted IROMPs fraction which had been treated with proteinase $\mathrm{K}$ to digest the protein components. By using an ELISA procedure, it was shown that MAbs $3 \mathrm{~A} 1$, $3 \mathrm{~A} 3,6 \mathrm{G} 2$, and $9 F 7$ reacted both with the proteinase-Ktreated and the untreated fractions, MAb $2 \mathrm{G} 3$ reacted only with the untreated IROMPs fraction, and MAb $3 \mathrm{C} 6$ reacted with the untreated IROMPs fraction and showed a weak reaction with the treated fraction and with extracted LPS (Table 2).

The responses of the MAbs to strain MT 423 grown under iron-restricted and iron-supplemented condi- tions were similar to those observed when the bacteria were cultured in TSB (Table 2).

\section{Binding of MAbs to whole and lysed bacteria}

The responses of the MAb in ELISA to the various Aeromonas salmonicida isolates are shown in Table 3. A strong response was noted for all isolates by the monoclonals against LPS, while a weak positive response (3C6) and essentially no response (2G3) were obtained with the monoclonals against IROMPs. The reactivity of the MAbs was not affected by the presence (e.g. strains MT 423) or absence (e.g. strains B93292) of A layer protein in the various $A$. salmonicida strains included in the test. MAb directed against

Table 2. Responses of monoclonal antibodies (MAbs) in an enzyme-linked immunosorbent assay to bacterial preparations of Aeromonas salmonicida strain MT 423

\begin{tabular}{|c|c|c|c|c|c|c|}
\hline \multirow{2}{*}{ Source of antigen } & \multicolumn{6}{|c|}{ Absorbance $(450 \mathrm{~nm})$ with the indicated MAbs ${ }^{a}$} \\
\hline & $3 \mathrm{~A} 1$ & $3 \mathrm{~A} 3$ & $2 \mathrm{G} 3$ & $6 \mathrm{G} 2$ & $9 \mathrm{~F} 7$ & $3 \mathrm{C} 6$ \\
\hline TSB (+ve control) & 1.03 & 1.08 & 0.12 & 1.13 & 0.87 & 0.69 \\
\hline $\mathrm{TSB}+\operatorname{Dipy}(0.1 \mathrm{mM})$ & 1.01 & 1.06 & 0.14 & 1.15 & 0.85 & 0.61 \\
\hline $\mathrm{TSB}+\mathrm{FeSO}_{4}(0.1 \mathrm{mM})$ & 1.08 & 1.13 & 0.15 & 1.16 & 0.97 & 0.58 \\
\hline IROMPs extracted from TSB + Dipy & 1.78 & 1.81 & 1.19 & 1.76 & 1.70 & 1.28 \\
\hline Proteinase K-treated IROMPs extracted from TSB + Dipy & 1.86 & 1.78 & 0.27 & 1.73 & 1.71 & 0.6 \\
\hline LPS extracted from TSB + Dipy & 1.73 & 1.60 & 0.16 & 1.86 & 1.83 & 0.49 \\
\hline TBS, then lysed & 1.08 & 1.14 & 0.18 & 1.20 & 0.91 & 0.32 \\
\hline TSB + Dipy, then lysed & 1.06 & 1.14 & 0.25 & 1.20 & 0.92 & 0.31 \\
\hline PBS (no antigen) & 0.11 & 0.11 & 0.11 & 0.13 & 0.14 & 0.11 \\
\hline
\end{tabular}


LPS (3A1, 3A3, 6G2 and 9F7) also reacted with whole bacteria by IFAT (Fig. 3). Of the 2 MAbs (2G3 and $3 \mathrm{C} 6$ ) against the IROMPs, 2G3 did not react with whole bacteria but 3C6 showed a weak reaction (Fig. 3). However, both MAbs showed a strong reaction against electroeluted IROMPs (Table 2).

Rupturing the bacteria by sonication $(6 \times$ 30 s) before sensitising the microtitre plates with the sonicated cell suspension did not improve the reactivity of the antiIROMPs monoclonal antibodies in the ELISA procedure.

\section{Cross-reactivity of MAbs with a range of bacteria}

A negative response by ELISA to the various bacterial cultures listed in Table 1 showed that the MAb to the LPS (3A1, $3 \mathrm{~A} 3,6 \mathrm{G} 2$ and 9F7) and IROMPs (2G3 and $3 \mathrm{C}$ ) ) were specific for Aeromonas salmonicida (data not shown).

\section{DISCUSSION}

After electroelution from the crude OMPs preparations of Aeromonas salmonicida, both the electrophoretic mobility and the sharpness of the bands of the proteins in the IROMPs-containing fraction increased (Fig. 1a). These changes could reflect the removal of some other components associated with the IROMPs. Fig. 1 also shows that the IROMPs fraction contained LPS. Both components could be stained by the silver reagent, but only the protein by Coomassie Blue. The treatment with proteinase $K$ largely, if not completely, destroyed the IROMPs and removed the Coomassie Blue staining bands, but left the LPS intact. This illustrates the need to exercise caution when interpreting results where only Coomassie Blue staining is used to detect the outer membrane proteins. The presence of the 2 types of antigens in the IROMPs-containing fraction led to the production of 2 types of MAbs. Four MAbs were prepared against LPS and 2 against IROMPs; the specificities of these were demonstrated by ELISA and immunoblotting using the IROMPs containing fraction and extracted LPS.

When the MAbs were reacted with whole bacteria, it was found that the anti-LPS antibodies gave positive
Table 3. Responses of monoclonal antibodies (MAbs) to intact cells of various Aeromonas salmonicida isolates in an enzyme linked immunosorbent assay

\begin{tabular}{|c|c|c|c|c|c|c|}
\hline \multirow{2}{*}{$\begin{array}{l}\text { A. salmonicida } \\
\text { isolates }{ }^{d}\end{array}$} & \multicolumn{6}{|c|}{ Absorbance $(450 \mathrm{~mm})$ with the indicated MAbs } \\
\hline & $3 A 1$ & $3 \mathrm{~A} 3$ & $6 \mathrm{G} 2$ & $9 \mathrm{~F} 7$ & $3 \mathrm{C} 6$ & $2 \mathrm{G} 3$ \\
\hline MT 423 (+ve control) & 0.96 & 1.33 & 1.03 & 1.09 & 0.58 & 0.18 \\
\hline PBS (no antigen) & 0.11 & 0.10 & 0.11 & 0.11 & 0.09 & 0.10 \\
\hline $\mathrm{B} 92406 \mathrm{~K}$ & 0.82 & 1.04 & 0.84 & 0.70 & 0.31 & 0.17 \\
\hline B3200 406 & 0.66 & 0.76 & 0.51 & 0.50 & 0.27 & 0.12 \\
\hline B92337 (3) & 0.90 & 1.14 & 0.79 & 0.76 & 0.27 & 0.11 \\
\hline B93058 & 0.59 & 0.91 & 0.53 & 0.42 & 0.17 & 0.10 \\
\hline B93189 NCB7 $7^{\circ}$ & 0.85 & 1.04 & 0.71 & 0.67 & 0.21 & 0.12 \\
\hline B92431 V254 & 0.92 & 1.11 & 0.81 & 0.71 & 0.17 & 0.10 \\
\hline $\mathrm{B} 93292 \mathrm{I}_{\mathrm{i}}(\mathrm{s})$ & 0.86 & 0.96 & 0.81 & 0.70 & 0.31 & 0.12 \\
\hline B92415 S9 & 0.75 & 0.97 & 0.60 & 0.67 & 0.33 & 0.12 \\
\hline B93220 PA10 & 0.85 & 1.03 & 0.80 & 0.66 & 0.34 & 0.09 \\
\hline B92343 4B71 & 1.02 & 1.29 & 0.93 & 0.86 & 0.33 & 0.14 \\
\hline B93205 K & 0.97 & 1.17 & 0.84 & 0.85 & 0.32 & 0.13 \\
\hline B93292 E4(2) & 0.93 & 1.21 & 0.88 & 0.81 & 0.28 & 0.11 \\
\hline B93292 11(4) & 0.89 & 1.16 & 0.84 & 0.77 & 0.22 & 0.13 \\
\hline B93292 11(1) & 0.80 & 1.01 & 0.58 & 0.68 & 0.21 & 0.11 \\
\hline B93292 E3 & 0.86 & 1.03 & 0.86 & 0.72 & 0.31 & 0.12 \\
\hline B93186 C14K & 0.99 & 1.25 & 0.81 & 0.88 & 0.30 & 0.16 \\
\hline B93244 ". & 0.80 & 1.12 & 0.87 & 0.71 & 0.26 & 0.11 \\
\hline B93292 B4(1) & 0.91 & 1.13 & 0.83 & 0.83 & 0.35 & 0.14 \\
\hline B92483 B2 & 0.92 & 1.11 & 0.94 & 0.91 & 0.30 & 0.13 \\
\hline B93292 11(3) & 0.89 & 1.14 & 0.81 & 0.84 & 0.28 & 0.10 \\
\hline B93246 V190 & 0.89 & 1.15 & 0.84 & 0.79 & 0.25 & 0.14 \\
\hline B93257 & nd & 1.16 & 0.61 & 0.79 & 0.18 & 0.11 \\
\hline B93058 (S) & 0.68 & 0.93 & 0.89 & 0.59 & 0.29 & 0.12 \\
\hline B93204 C10K & 0.96 & 1.20 & 0.84 & 0.80 & 0.34 & 0.15 \\
\hline B93079 B4 & 0.95 & 1.16 & 1.00 & 0.81 & 0.38 & 0.12 \\
\hline B92415 PNG1 & 0.95 & 1.15 & 0.91 & 0.87 & 0.31 & 0.13 \\
\hline B93292 11(2) & 0.98 & 1.20 & 0.91 & 0.89 & 0.29 & 0.14 \\
\hline B92423 PNG1 & 0.96 & 1.20 & 0.96 & 0.86 & 0.28 & 0.15 \\
\hline B92346 V189 & 0.93 & 1.24 & nd & 0.85 & 0.27 & 0.13 \\
\hline $\begin{array}{l}\text { dAll isolates were typ } \\
\text { Atlantic salmon, exce } \\
{ }^{b} \text { The data shown repre } \\
\text { fering by less than } 5 \\
\text { Abs as determined b } \\
\text { anti-IROMPs Abs as }\end{array}$ & $\begin{array}{l}\text { for }{ }^{\circ} \\
\text { ent the } \\
\text { MA } \\
\text { weste } \\
\text { etermir }\end{array}$ & $\begin{array}{l}\text { bow } \\
\text { verag } \\
3 \text { A } 1 \\
\text { blot a } \\
\text { by } w\end{array}$ & $\begin{array}{l}\text { atioge } \\
2 \text { rea } \\
3,6 \mathrm{G} 2 \\
\text { ysis; } M \\
\text { tern bl }\end{array}$ & $\begin{array}{l}\text { all } \\
\text { brow } \\
\text { igs fo } \\
\text { nd } 91 \\
\text { bs } 20 \\
\text { andily }\end{array}$ & $\begin{array}{l}\text { out } \\
\text { ch isc } \\
\text { vere } \\
\text { nd } 3\end{array}$ & $\begin{array}{l}\text { from } \\
\text { e dif- } \\
\text {-LPS } \\
\text { were } \\
\text { done }\end{array}$ \\
\hline
\end{tabular}

responses (i.e. one could recognise the whole bacterial antigen). However, in the case of the anti-IROMPs antibodies (as determined by western blotting), one showed a weak recognition (3C6) and the other (2G3) showed no reaction with intact Aeromonas salmonicida cells. This suggests that whereas the LPS epitopes are clearly exposed on the bacterial surface, the IROMPs recognised by $3 \mathrm{C} 6$ and $2 \mathrm{G} 3$ are less exposed. Indeed, the IROMPs recognised by $2 \mathrm{G} 3$ appear not to be exposed and could well be embedded in the membrane. From the data shown in Table 2, it appears that MAb 3C6 shows a weak reaction against both proteinase K-treated IROMPs and extracted LPS. This 

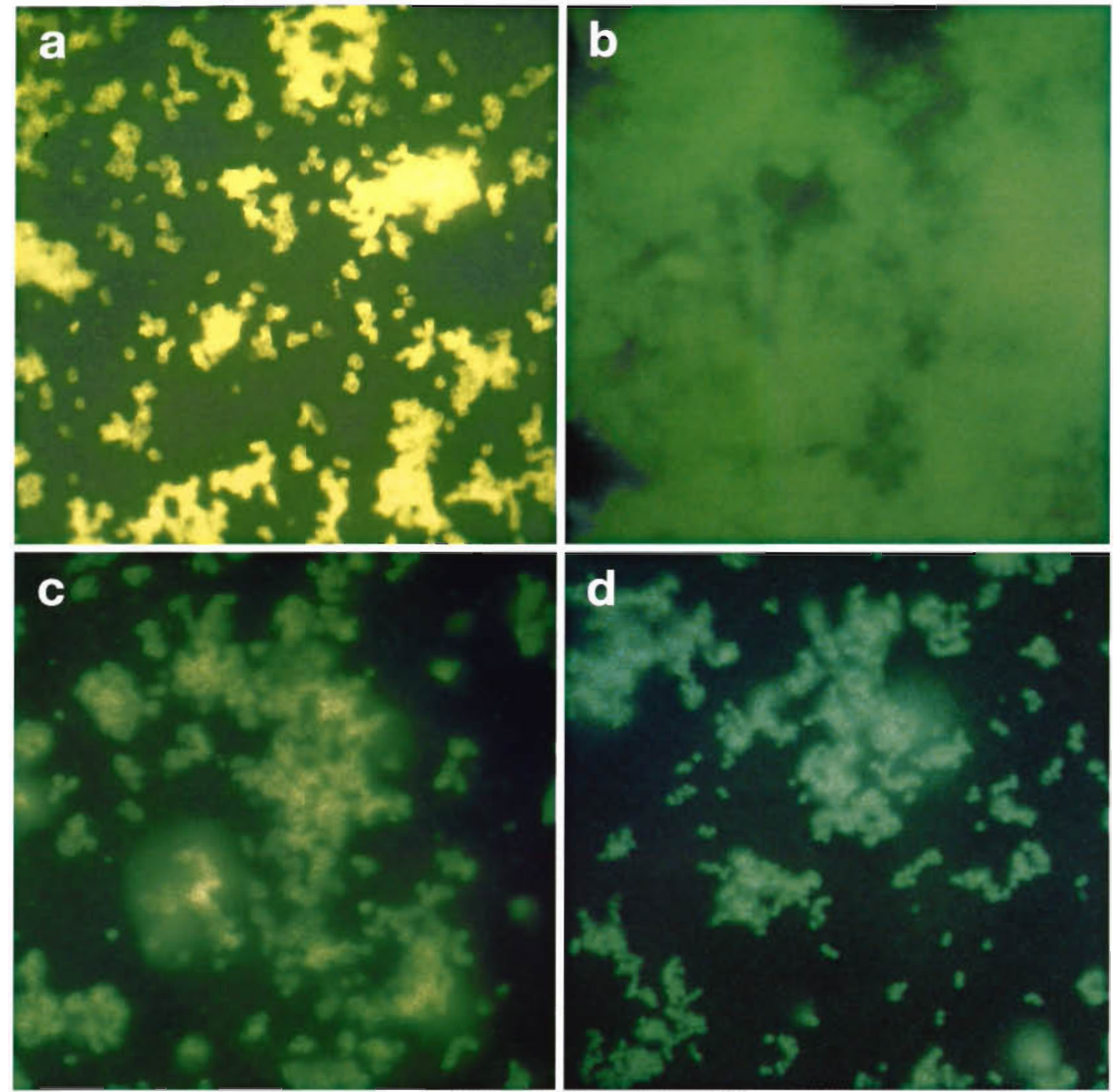

Fig. 3. Reaction of MAb with Aeromonas salmonicida cells by the indirect fluorescent antibody test. The plates show the reactions obtained with: (a) 9F7 (an LPS MAb), (b) 2G3 (an IROMP MAb showing no reaction with the cells). (c) 3C6 (an IROMP MAb showing a weak reaction with the cells) and (d) negative control (1/100 dilution of normal mouse serum). $\times 1000$

might arise from the presence of residual traces of IROMPs in these preparations.

The MAbs described in this paper should be of considerable value for detecting typical forms of Aeromonas salmonicida and quantifying their levels of IROMPs and LPS. In some preliminary experiments it was found that Haemophilus piscium, believed to be an atypical $A$. salmonicida which is serologically indistinguishable from $A$. salmonicida (Paterson et al. 1980), and which reacts with polyclonal sheep anti- $A$. salmonicida serum (Adams \& Thompson 1990), did not react with the MAbs. Hence the MAbs may also be of value in distinguishing between typical and atypical strains of $A$. salmonicida.
Acknowledgements. The authors thank the Scottish Salmon Growers Association and the Crown Estates Commissioners for funding this project and Dr V. Inglis and Gillian Dreczkowski for supplying Aeromonas salmonicida isolates.

\section{LITERATURE CITED}

Adams A, Richards RH, Marin de Mateo M (1992) Development of monoclonal antibodies to PK ' $\mathrm{X}$ ', the causative agent of proliferative kidney disease. J Fish Dis 15:515-521 Adams A, Thompson KD (1990) Development of an enzymelinked immunosorbent assay (ELISA) for the detection of Aeromonas salmonicida in fish tissue. J aquat Anim Health 2:281-288

Anderson DP (1990) Fluorescent antibody test. In: Stolen JS, Fletcher TC, Anderson DP, Robertson BS, van Muiswinkel 
WB (eds) Techniques in fish immunology, Vol I. SOS Publications, Fair Haven, NJ, p 1-8

Chart $H$. Trust TJ (1983) Acquistion of iron by Aeromonas saimonicida. J Bacteriol 156:758-64

Filip C, Fletcher G, Wulff JL, Earhart CF (1973) Solubilization of the cytoplasmic membrane of Escherichia coli by the Ionic detergent sodium laurylsarcosinate. J Bacteriol 115: $717-722$

Harlow E, Lane D (1988) Antibodies, a laboratory manual. Cold Spring Harbor Laboratory Press, Cold Spring Harbor, NY, p 68

Hirst ID (1993) Characterisation of the iron uptake mechanisms in Aeromonas salmonicida: role in virulence and protective immunity. PhD thesis, University of Stirling

Hirst ID, Ellis AE (1994) Iron-regulated outer membrane proteins of Aeromonas salmonicida are important protective antigens in Atlantic salmon against furunculosis. Fish Shellfish Immunol 4:29-46

Khyse-Andersen $J$ (1984) Electroblotting of multiple gels: a simple apparatus without buffer tank for rapid transfer of proteins from polyacrylamide to nitrocellulose. $J$ biochem biophys Meth 10:203-209

Laemmli UK (1970) Cleavage of structural proteins during assembly of the head of bacteriophage T4. Nature 227 :

Responsible Subject Editor: T. Evelyn. Nanaimo, B.C., Canada
680-685

Markwell MAK, Haas SM, Tolbert NE, Bieber LL (1981) Protein determination in membrane and lipoprotein samples: manual and automated procedures. Meth Enzymol 72: $296-303$

Neelam B, Robinson RA, Price NC, Stevens L (1993) The effect of iron limitation on the growth of Aeromonas salmonicida. Microbios 74:59-67

Paterson WD, Douey D, Desutels D (1980) Relationship between selected strains of typical and atypical Aeromonas salmonicida in diseased fish tissue. Develop biol Standard 49:97-100

Price NC, Stevens L, Duncan D, Snodgrass M (1989) Proteases secreted by strains of Aeromonas salmonicida. J Fish Dis 12:223-232

Towbin $H$, Staehelin T, Gordon J (1979) Electrophoretic transfer of proteins from polyacrylamide gels to nitrocellulose sheets: procedure and some applications. Proc Natl Acad Sci USA 76:4350

Trust TJ (1986) Pathogenesis of infectious diseases of fish. A Rev Microbiol 40:479-502

Westphal O, Jann K (1965) Bacterial lipopolysaccharide: extraction with phenol/water and further applications of the procedure. Meth Carbohydrate Chem 5:83-91

Manuscript first received: December 22, 1993

Revised version accepted: October 21, 1994 